\title{
Individual contracting, collective bargaining and wages in Australia ${ }^{1}$
}

\author{
David Peetz \\ Department of Employment Relations, \\ Griffith Business School, \\ Griffith University, \\ Brisbane QLD 4111 Australia \\ email: d.peetz@griffith.edu.au \\ tel: +61 737357600 \\ fax: +61 737357177
}

\begin{abstract}
Alison Preston
Graduate School of Business

Curtin University of Technology,

78 Murray Street, Perth 6000.

Tel: + 61892667900
\end{abstract}

Email: Alison.Preston@gsb.curtin.edu.au

forthcoming, Industrial Relations Journal, 2009

\footnotetext{
${ }^{1}$ David Peetz is Professor of Industrial Relations at Griffith University. Alison Preston is Professor of Economics and Director of the Graduate School of Business at Curtin University of Technology. Correspondence should be addressed to David Peetz, Griffith Business School, Griffith University, Brisbane, QLD 4111, Australia. Email d.peetz@griffith.edu.au.
} 


\title{
Individual contracting, collective bargaining and wages in Australia ${ }^{2}$
}

\begin{abstract}
We examine wages in Australia under federally-registered individual contracts and collective agreements using unpublished data from a national earnings survey. The distribution of earnings under registered individual contracts was more unequal than under collective agreements. Average and median earnings under registered individual contracts were lower than under collective agreements. There was little evidence that individual contracting raised wages through raising productivity. The link between contracting and pay appears contingent, varying between occupations, industries and firm size bands, and dependent upon employees' position in the labour market and employers' use of union avoidance strategies. This has implications for the interpretation of studies of union wage effects.
\end{abstract}

\section{INTRODUCTION}

Since the 1980s, employers in several countries have sought to decollectivise employment relations by moving from collective relations with employees to more 'individualised' arrangements. In Britain, coverage in workplaces with 25 or more employees by collective agreements fell from 54 per cent of the workforce in 1990 to 38 per cent in 1998 and 34 per cent in 2004 (Charlwood 2007). Regulatory changes have encouraged this process, nowhere more so than in Australia and New Zealand. In 1991, the conservative New Zealand government introduced the Employment Contracts Act 1991 (ECA) which abolished tribunal wage determination, removed recognition of unions and promoted individual contracts. In Australia, with its federal system, change was more gradual. Laws inspired by, but milder than, the ECA were passed by conservative state and federal governments through the 1990s. The culmination, achieved only when a conservative government gained full control of the Upper House, was the 'WorkChoices’ legislation which took effect from March 2006.

\footnotetext{
2 This project was, in part, financially supported by Industrial Relations Victoria in the Victorian Department of Innovation, Industry \& Regional Development.
} 
The general direction of change in Australia was consistent with the spirit of policies advocated for some time by the Organisation for Economic Cooperation and Development (OECD), which praised Australia for 'its remarkable progress from a very unsatisfactory starting point' (OECD 2004a). Many labour market reforms were in keeping with the 1994 OECD Jobs Study's strategy (OECD 1994). Australia was 'among the OECD countries complying best' with it (OECD 2001: 14). Amongst other things, Australian reforms aimed to: increase working time flexibility; boost employment participation by changing the welfare system; and further decentralise and individualise wage bargaining to increase wage flexibility. More recently, the OECD has hedged its position somewhat regarding policy effects. Its 2004 Employment Outlook indicated its previously asserted link between high or compressed wage structures and lower employment had 'plausibility' but the evidence was ‘fragile’ (OECD 2004b:165). Is 2006 Employment Outlook, analysing econometric literature, observed: the effect of employment protection legislation on overall unemployment 'was probably small'; most studies found no significant union impact on overall labour market performance; a high degree of corporatism (centralisation) was associated with lower unemployment; and evidence on the link between minimum wages and employment was 'ambiguous'. All these findings were confirmed by its own econometric analysis (OECD 2006b: 96,84,85,86,212,217). While observing that several countries with highly regulated labour markets and active labour market programs (Austria, Denmark, Ireland, the Netherlands, Norway and Sweden) had on average better employment rates than 'market reliant' countries such as the UK, USA, Australia and New Zealand, and conceding 'there is no single combination of policies and institutions to achieve and maintain good labour market performance', the OECD continued to advocate 'flexible working-time arrangements' and 'wage flexibility', with qualifications (OECD 2006a: 18,12,13). Such nuances in OECD analysis were not reflected in Australian government policy in the development and implementation of the ‘WorkChoices’ reforms. (Cowling \& Mitchell 2006).

In this paper we use unpublished Australian data from a national earnings survey to understand the patterns, trends and effects of individual wage bargaining. How has individual bargaining affected wage relativities at particular levels including national, industry, occupational, firm and between men and women? Has individualisation promoted higher wages through improved productivity growth at national and industry levels? Is there a link between the wage effects of individualisation and management strategies regarding 
unions? In privileging individual bargaining over collective bargaining, the Australian industrial relations system provides a unique opportunity for this type of study.

\section{SOME THEORETICAL CONSIDERATIONS}

Rubery (1997) notes that wages serve three broad functions: (a) price allocation; (b) social stratification/social cohesion; and (c) management tool. The price allocation function (the traditional OECD position), discussed earlier, holds that wage differentials, when unimpeded by state distortions, reflect labour productivity differentials and promote an efficient allocation of labour resources. Within this framework individual contracting is typically seen as most beneficial (providing the greatest level of flexibility), although the recent OECD evidence raises questions about this. The social function derives from social wage theory, in which wage rates reflect both economic and social considerations - a combination of 'what the market will bear' and perceived 'fair' distributions of rewards (Blinder \& Choi 1990). The management tool function emphasises management's strategic pay decisions and factors shaping their choice of pay instrument. Here, wages present an important tool for manipulation of labour. In one form of the efficiency wage literature, for example, 'union threat models' have emerged to explain strategies of matching or exceeding conditions obtainable by unions, to remove workers' incentive to organise (Dickens 1986,Corneoa \& Luciforab 1997). Individual contracting may provide a mechanism for paying a non-union premium and precluding collective bargaining (Brown et al. 1998; Dundon \& Rollison 2004; Hearn Mackinnon 2007).

Centralised wage systems, unions and collective bargaining are generally associated with more compressed wage structures (Freeman 1980; Metcalf 1982; Charlwood 2007). Evidence from the OECD shows increased wages dispersion within most OECD countries in recent years. Consistent with theory, it is particularly present in countries pursuing more flexible wage setting arrangements such as Australia (OECD 2004b: ch 3). Between 1991 and 2005 the 90/10 earnings decile ratio increased by 11 per cent (from 2.8 to 3.1) in Australia while the incidence of low pay increased by 14 per cent (from 13.9 to 15.9 percent). Over the same period the 90/10 earnings decile in the UK widened by six per cent (to 3.6) while the incidence of low paid increased by eight per cent (to 20.9 per cent) (OECD 2008). Other aspects of the Australian wage structure show related trends, including a widening gender pay gap, particularly amongst part-time employees (Preston \& Jefferson 2007). 
But if greater individualisation of pay leads to greater pay dispersion, is this a bad thing? Does individualisation promote more efficient resource allocation, as per the 1990s OECD model, to unleash constraints on efficiency, leading to higher productivity and hence wages? This rationale was advanced by Australian policy makers to justify the 'WorkChoices' reforms (eg Andrews 2005,2006). This might appear counter to many studies from the USA, Britain, Australia and elsewhere showing unions obtain higher wages for members than nonmembers achieve, though the size of the union premium appears to be declining over time (Freeman \& Medoff 1984; Miller \& Rummery 1989; Christie 1992; Kornfeld 1993; Baarth, Raaum \& Naylor 1998; Hildreth 2000; Wooden 2000; Fang \& Verma 2002; Forth \& Millward 2002; Blanchflower \& Bryson 2003). British evidence from Charlwood (2007) suggested little difference in most performance indicators between workplaces that maintained and those that abandoned collective bargaining in favour of individualised approaches. Where there were differences, workplaces that had abandoned collective bargaining had weaker improvements in productivity. Does individual contracting offer an assumed 'efficiency wage' benefit, in that employers pay a premium in the belief that they will reap benefits from having a non-unionised workforce? Or does individualisation increase dispersion because workers with less skill and bargaining power lose out due to widening power gaps under individualisation?

Our study of Australian data does not seek in the space available to systematically answer all these questions, but it touches aspects of each and raises points about the interpretation of studies of union wage effects. We undertake this analysis in the context of the 'WorkChoices' reforms, which took effect two months before the data were collected. These reforms are described elsewhere in this volume (Bailey, Mourell \& Wilkinson 2009), so details are not repeated here. The key element relevant to this analysis is Australian Workplace Agreements (AWAs), individual contracts that can be inconsistent with award conditions and registered in the federal jurisdiction. These were introduced in 1997 by the new conservative government, which also created extensive opportunities for non-union 'collective' agreements. From March 2006 a new federal industrial relations framework, entitled 'WorkChoices' privileged individual contracting over collective bargaining, including by allowing individual agreements to over-ride collective agreements and abolished the nodisadvantage test for AWAs and collective agreements (by which agreements had been meant to provide conditions no worse in net terms than the relevant tribunal-determined award that 
applied to those employees). Various other statutory individual contracts had existed in state government jurisdictions, but by the time of 'WorkChoices' these had considerably stronger minimum standards than AWAs, due to the ascendancy of Labor governments at state level, and had mostly, but not entirely, disappeared.

\section{DATA}

Although we utilise published labour force and national accounts data from the Australian Bureau of Statistics (ABS), most of this paper relies on unpublished data from its Employee Earnings and Hours Survey (EEH) for May 2006. EEH collected information on 57,000 employees working for 9,000 Australian employers and separately identified the different types of formal wage fixing arrangements employees were paid under, including different types of individual contracts.

There are two types of individualisation observable in EEH: formalised, through the use of statutory individual contracts such as AWAs; and very broadly defined 'individual arrangements'. The former is a subgroup of the latter. The latter also includes 'common law' contracts where pay is above the minimum set out in tribunal awards or collective agreements and some employees who have no underpinning award. Common law contracts had existed since the foundation of the Australian system over a century ago, whereas AWAs were a new form of flexibility. While some employers since the 1990s have used common law contracts to try to circumvent union coverage, there were limits to their usefulness, because no aspect of their pay and conditions could legally be below those stated in awards or agreements. Because of this 'floor', Australian common law contracts do not offer a true insight into the impact of individual bargaining on pay and conditions, and are not really comparable to individual contracts in Britain. The flexibilities provided by AWAs are a closer approximation of the freedom of contracting available to British employers operating outside collective bargaining. So, while we use both indicators of individualisation in the first table, which summarises some general patterns, when we discuss earnings through the rest of the article, we focus on the effects of the statutory form, AWAs, through which employers had freedom to choose or negotiate the conditions they sought. We wish to compare workers on AWAs with workers on collective agreements. 
EEH is the most reliable source of data on earnings of employees under AWAs (McIlwain 2006). However, we need to interrogate unpublished data from it, as the published data do not separately identify workers on AWAs (ABS publications do not distinguish them from the far less common individual contracts registered under Labor-governed state systems, with far more stringent requirements). Our focus is on hourly cash earnings of non-managerial employees (the ABS does not collect data on hourly earnings for managerial employees). Unfortunately, the data did not permit us to undertake multivariate analysis that could for employee characteristics such as age, qualifications and experience .

We compare AWAs with registered collective agreements (referred to as CAs). However, another weakness in the data is that they do not distinguish between union and non-union collective agreements CAs. Unlike in most countries, a 'collective agreement' in Australia can be negotiated with a group of employees without union representation. It can just be presented to them, to vote on. Over one in ten employees on collective agreements are on non-union agreements. Non-union CAs incorporate, on average, lower wage increases than union CAs, and in industries such as retail trade and hospitality substantially weaker employment conditions. They were often used to substitute or provide transition onto AWAs (Department of Employment and Workplace Relations 2006; Workplace Research Centre 2006; Enterprise Initiatives 2007; Evesson et al. 2007). Hence average earnings of employees under CAs understate the earnings of employees under union collective bargaining, especially in retail and hospitality. Australia also has a relatively high rate of free riding - two fifths of employees covered by union collective agreements do not belong to a union (Teicher et al. 2007), reducing bargaining strength of unions negotiating CAs in many workplaces.

Because of potential sampling error, where possible we seek verification of trends by considering whether similar patterns are apparent in May 2004 data.

A final limitation is that most wage data are expressed as averages, which can be biased by inclusion of a few observations of employees with very high earnings. A more representative 
indicator of the situation of the 'typical' worker is provided by median earnings, and we use these where available - at the aggregate level.

\section{FINDINGS}

\section{Productivity, earnings and individual contracting}

Before examining hourly earnings under collective agreements and individual contracts, we first overview industry level patterns in individual agreement coverage, union density, and growth in hourly earnings and labour productivity. Results are in Table 1, which includes Pearson correlations of two measures of individual agreements - AWA coverage, and growth in all individual arrangements (including common law contracts), from the EEH survey with union density, hourly earnings and productivity growth. The data cover from 2000 (when EEH survey data on individual agreements were first available) to 2006 (the latest EEH data we had access to at time of writing). Two sources of data on hourly earnings growth are used: EEH and the ABS Labour Price Index which, unlike EEH, controls for compositional changes within an industry and so is considered a more reliable indicator of change. Several observations can be made. 


\begin{tabular}{|c|c|c|c|c|c|c|c|c|}
\hline \multirow[t]{2}{*}{ Variable: } & \multirow{2}{*}{$\begin{array}{l}\text { AWA } \\
\text { coverage } \\
\text { EEH }\end{array}$} & \multicolumn{2}{|c|}{$\begin{array}{l}\text { all individual } \\
\text { arrangements }^{(a)}\end{array}$} & \multirow{2}{*}{\multicolumn{2}{|c|}{$\begin{array}{c}\text { union density } \\
\text { Union membership } \\
\text { survey }\end{array}$}} & \multicolumn{2}{|c|}{ hourly earnings growth } & \multirow{2}{*}{$\begin{array}{l}\text { labour } \\
\text { productivity } \\
\text { growth } \\
\text { National } \\
\text { accounts }\end{array}$} \\
\hline & & \multicolumn{2}{|c|}{ EEH } & & & EEH & $\begin{array}{l}\text { Labour Price } \\
\text { Index }\end{array}$ & \\
\hline Industry & 2006 & 2006 & $\begin{array}{c}\text { Change }^{(b)} \\
2000- \\
2006\end{array}$ & 2006 & $\begin{array}{c}\text { Change }^{(b)} \\
2000-2006\end{array}$ & 2000-2006 & $2000-2006$ & $\begin{array}{l}2000- \\
2006\end{array}$ \\
\hline Mining & 16.2 & 67.8 & 13.5 & 22.9 & -9.4 & 4.9 & 4.0 & -5.6 \\
\hline Communication Services & 15.6 & 37.8 & 8.7 & 25.1 & -12.7 & 4.5 & 3.2 & 4.2 \\
\hline Transport and Storage & 6.2 & 47.1 & 5.6 & 29.1 & -7.3 & 4.8 & 3.4 & 3.0 \\
\hline Retail Trade & 5.4 & 36.5 & 0.0 & 16.1 & -1.6 & 4.2 & 3.1 & 2.1 \\
\hline Accommodation, Cafes and Restaurants & 4.3 & 34.0 & 5.4 & 8.1 & -2.2 & 4.0 & 3.1 & 2.6 \\
\hline Manufacturing & 3.3 & 51.7 & 0.1 & 23.4 & -7.8 & 5.3 & 3.6 & 2.6 \\
\hline Government Administration and Defence & 3.1 & 7.6 & 0.8 & 34.2 & -2.5 & 4.8 & 3.7 & \\
\hline Property and Business Services & 3.1 & 61.3 & -6.9 & 5.3 & -3.9 & 4.8 & 3.9 & \\
\hline Finance and Insurance & 2.8 & 52.3 & 7.9 & 13.4 & -10.9 & 6.2 & 3.8 & 1.5 \\
\hline Wholesale Trade & 2.1 & 77.7 & 0.6 & 8.0 & -2.4 & 5.3 & 3.4 & 4.3 \\
\hline Construction & 1.0 & 60.3 & -0.9 & 21.5 & -4.9 & 5.1 & 4.3 & 1.7 \\
\hline Personal and Other Services & 1.0 & 30.1 & 0.0 & 26.4 & -1.4 & 3.2 & 3.5 & \\
\hline Cultural and Recreational Services & 0.9 & 40.1 & -7.7 & 11.9 & -5.1 & 5.2 & 3.5 & 1.4 \\
\hline Electricity, Gas and Water Supply & 0.6 & 14.7 & -7.4 & 43.3 & -9.9 & 4.6 & 4.7 & -4.5 \\
\hline Education & 0.4 & 6.7 & -2.6 & 40.3 & -3.7 & 4.3 & 4.3 & \\
\hline Health and Community Services & 0.3 & 16.2 & -2.9 & 27.1 & -5.2 & 5.3 & 3.8 & 0.9 \\
\hline Total & 3.1 & 39.9 & -0.1 & 20.3 & -4.4 & 4.9 & 3.7 & 1.7 \\
\hline $\begin{array}{l}\text { correlation with incidence of AWAs } 2006 \\
\text { correlation with growth in individual arrangements }\end{array}$ & 1.00 & 0.32 & 0.77 & 0.06 & 0.53 & -0.04 & -0.32 & -0.11 \\
\hline $2000-2006$ & 0.77 & 0.33 & 1.00 & 0.09 & 0.44 & 0.07 & -0.33 & 0.05 \\
\hline
\end{tabular}

Table 1: Coverage of individual agreements, union density, earnings and productivity growth, by industry (percentages), 2000 to 2006 
Source: ABS Cat Nos 6306.0, 5204.0, 6345.0 and 6310.0.

Note:

(a) Individual arrangements include common law contracts and AWAs.

(b) Percentage points. 
First, both measures of individual agreement-making were related to declining union density, consistent with workplace survey data suggesting a negative relationship between individual 'bargaining' and union membership (Wooden 1999). Several industries with active union avoidance behaviour by employers had both large drops in union density and a high incidence of AWAs (mining, communication) or at least significant growth in individual arrangements (finance). Extensive union avoidance strategies have been well documented in mining, communications, finance and, in a more mixed fashion, government administration (Background Briefing 2000; Browne 2000; Workplace Express 2005; World Competitive Practices 1999b,a; Peetz 2006; Hearn Mackinnon 2007; McDonald \& Timo 1996). A number of studies have shown the importance of union avoidance as a motivation for a shift to individual contracting (Gilson \& Wagar 1996; Bickley, Jefferson \& Travaglione 1999; World Competitive Practices 1999a,b). There is extensive evidence of individual contracts being effectively used in mining and communications to deunionise workforces, sometimes through offering higher wages in return for signing individual contracts, and refusing to promote or give pay rises to those who refuse (Van den Broek 2003; Hearn Mackinnon 2007). In government administration, the figures are muddied by the contradictory positions promoted by the federal, Coalition government, which embraced AWAs, and the state governments, all Labor, which all but abandoned individual contracting.

Second, neither the presence of AWAs nor growth in individual arrangements were systematically associated with higher rates of earnings growth. In the case of more reliable indicator of earnings growth, there were small negative associations. Third, industries with high rates of individual contracting did not show systematically higher productivity growth. Of course, such comparisons are influenced by the choice of start and end years (though in our case, we use the maximum period for which EEH data were available). It is possible productivity effects take time to fully play out, if there are effects on functional flexibility, technology and investment, but six to eight years is a reasonable time in which benefits of a policy should be observable. Extending the productivity data to 2008 changes the correlation from -0.11 to +0.01 , but still fails to suggest any positive relationship between individualisation and productivity. Aggregate national labour productivity data reinforce this impression. From June 2000 till June 2008, the peak period in which individualisation was encouraged, this grew only 1.9 per cent per annum, below the average 2.4 per cent achieved 
over the preceding 35 years (ABS Cat 5204.0). During the eight quarters WorkChoices was in force, annual labour productivity growth was only 0.6 per cent, well below rates normally achieved at that stage of the business cycle (ABS Cat 5206.0). While this does not demonstrate WorkChoices had a negative effect on productivity, there was nothing to suggest a positive policy impact on productivity at national or industry level.

\section{Earnings distributions and gender}

The distributions of hourly earnings for workers on AWAs and CAs in 2006 are shown in Figure 1. Two things emerge. First, earnings of non-managerial workers on AWAs are generally lower than for those on CAs, except at the top end of the distribution. Hence in 2006, employees on CAs earned an average of $\$ 27.30$ per hour, compared to $\$ 25.30$ per hour for employees on AWAs (Table 2). Employees on AWAs earned \$2.00 per hour less, that is they faced a shortfall of 7.3 per cent compared to workers on CAs. However, averages can be deceptive, as they can be distorted by a small number of employees with high earnings: 69 per cent of AWA employees earn less than average AWA hourly earnings. A more representative indicator showed that median AWA earnings in 2006 were only $\$ 20.50$ per hour, some $\$ 4.00$ per hour below median earnings for CA employees. That is, the median AWA worker earned 16.3 per cent less than the median CA worker in 2006. This represented a slight deterioration on the median AWA shortfall in 2004, which was 14.8 per cent. 


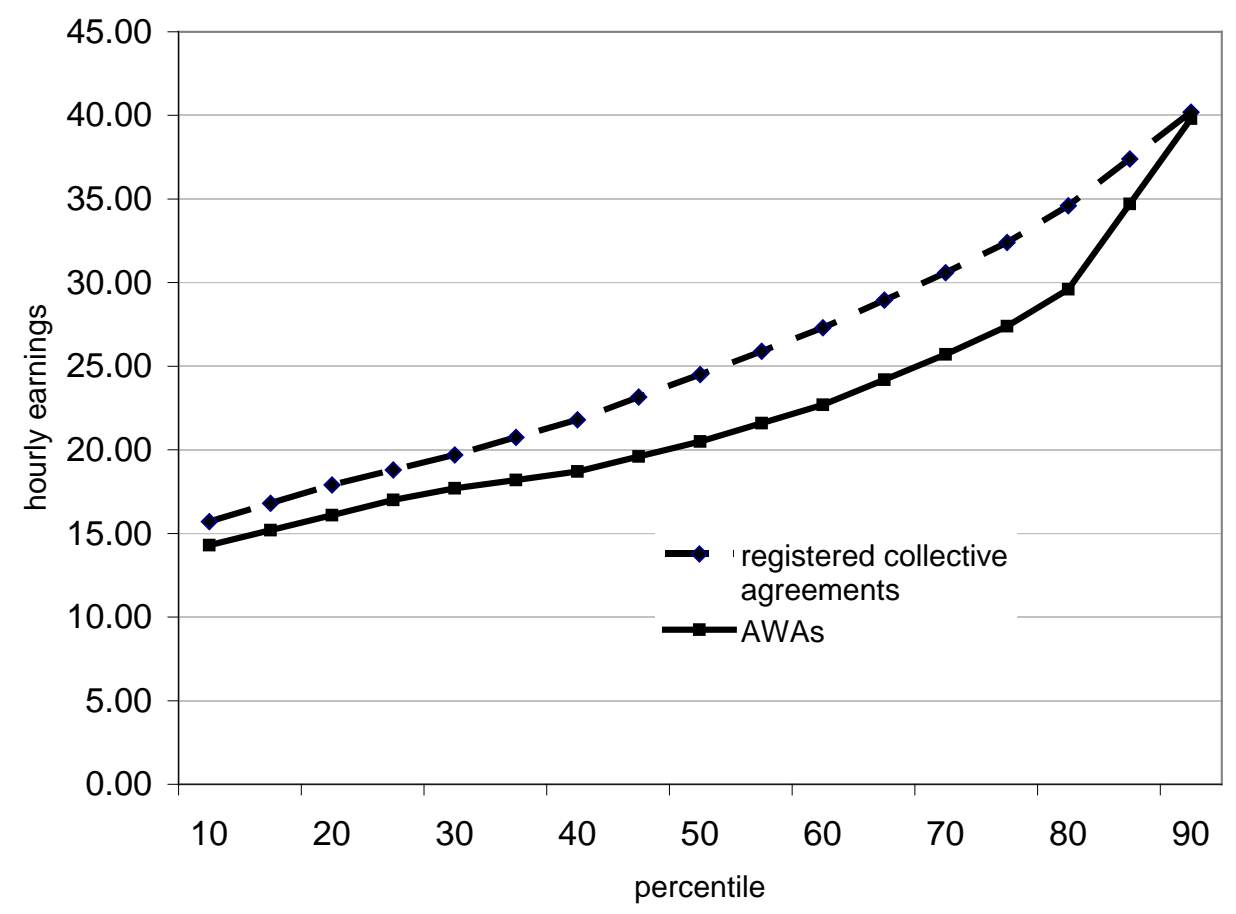

Figure 1: Average and hourly total cash earnings, by earnings percentile,

CAs and AWAs, 2006, non-managerial employees

Source: unpublished data from ABS Cat No 6306.0

\begin{tabular}{l|rr|rr|rr|} 
& \multicolumn{2}{|c|}{ CAs } & \multicolumn{2}{|c|}{ AWAs } & AWA/CA ratio \\
& $\begin{array}{l}2004 \\
(\$)\end{array}$ & 2006 & 2004 & 2006 & & \\
& $(\$)$ & $(\$)$ & $(\$)$ & 2004 & 2006 \\
\hline Average earnings \\
\hline Males & 25.80 & 28.70 & 25.80 & 26.50 & 1.000 & .923 \\
Females & 23.30 & 25.70 & 20.30 & 22.80 & .871 & .887 \\
Persons & 24.60 & 27.30 & 23.90 & 25.30 & .972 & .927 \\
\hline Median earnings & & & & & \\
\hline & & & & & \\
Males & 23.40 & 26.00 & 20.90 & 22.00 & .893 & .846 \\
& & & & & \\
Females & 21.40 & 23.00 & 17.30 & 18.70 & .808 & .813 \\
Persons & 22.30 & 24.50 & 19.00 & 20.50 & .852 & .837 \\
\hline
\end{tabular}

Table 2: Average and median hourly total cash earnings,

CAs and AWAs, 2004 and 2006, non-managerial employees

Source: unpublished data from ABS Cat No 6306.0 
Second, the distribution of earnings of non-managerial employees on AWAs was more unequal than for collective agreements. The Gini coefficient on the distribution of nonmanagerial earnings was .18 for workers on CAs, compared to .21 for those on AWAs. (Both numbers would be higher if managerial employees could be included.) The gender pay gap was also greater for workers on AWAs than on CAs. In 2006, men on median AWA earnings earned 15.4 per cent less than men on median CA earnings in 2006. The median earnings for female non-managerial employees on AWAs was 18.7 per cent lower than corresponding median for females on CAs. In 2004 the corresponding female AWA shortfall was similarly large, at 19.2 per cent.

\section{Firm size and agreements}

There was a stark relationship between the ratio of earnings under AWAs to earnings under CAs (the 'AWA/CA ratio') and firm size. The wage shortfall widened as organisations got smaller (Figure 2). The 2006 shortfall is 3.5 per cent amongst organisations with 100-499 employees, rises to 12.4 per cent in organisations with 50-99 employees, 13.6 per cent in organisations with 20-49 employees and is a very substantial 26.3 per cent in organisations with fewer than 20 employees. Amongst large organisations with more than 1000 employees (the majority of whom are covered by collective agreements), there is a wage premium for AWAs of 30.8 per cent. The 2004 data follow a broadly similar pattern. 


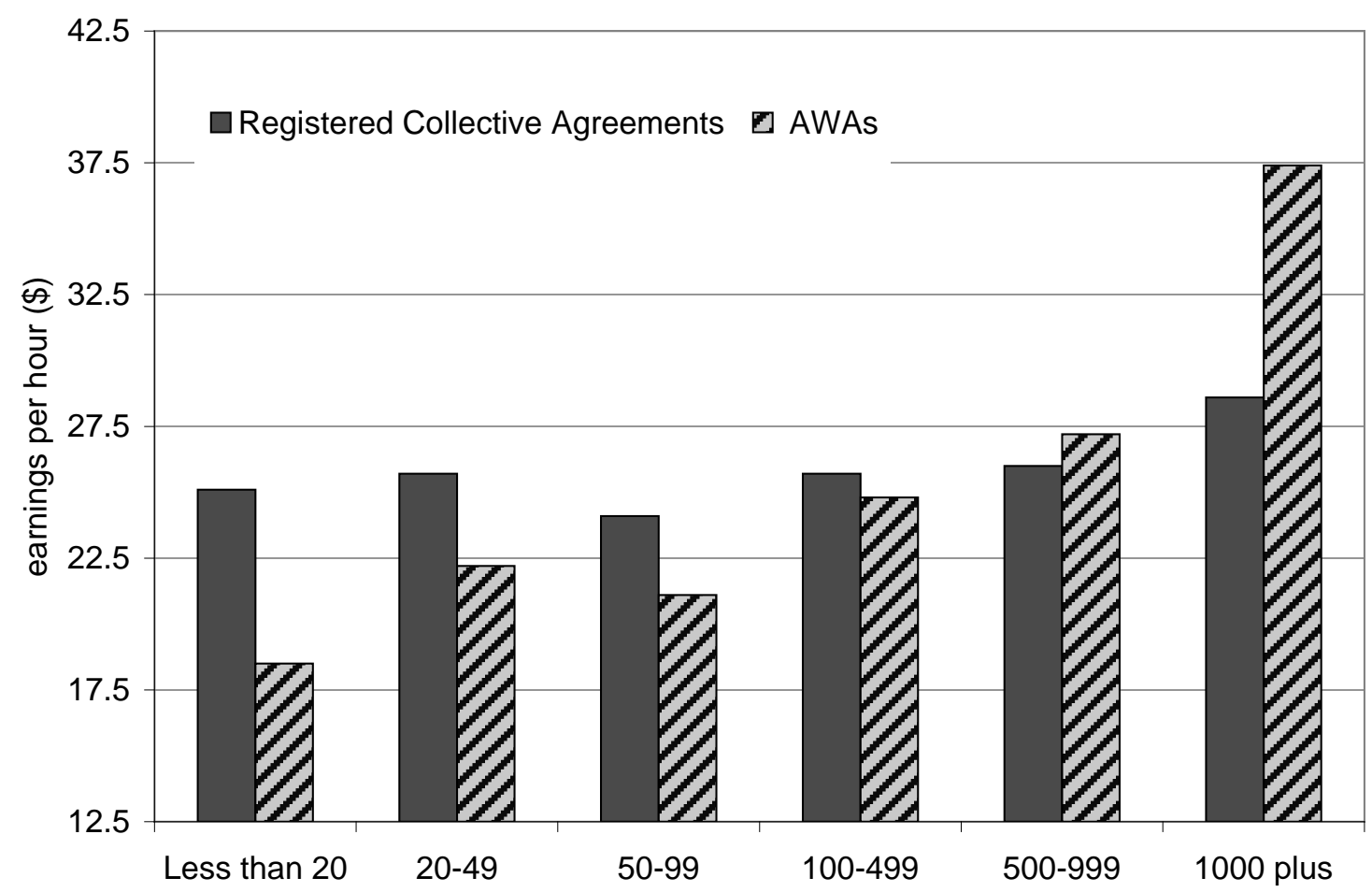

Figure 2: Average Total Hourly Cash Earnings by Firm Size and Method of Pay Setting, May 2006

Source: unpublished data from ABS Cat No 6306.0

\section{Industry and agreements}

Among the 16 one-digit industry groupings in Australia, at May 2006, the AWA/CA ratio was below 100 per cent in nine of the 16 industries. In other words, AWA employees in the majority of industries received a lower hourly rate on their AWA than their counterparts did on CAs.

In 2006 the industry with the highest AWA/CA ratio was communication services, at 1.50 (Figure 3). As mentioned, this is an industry where significant union avoidance behaviour has been underway. The second highest ratio (1.33) was in government administration and defence where, as previously indicated, a number of federal government agencies required the signing of an AWA as a precondition to advancement or a wage increase, again as part of a strategy aimed at reducing union influence. The third highest ratio (1.22) was in finance 
and insurance, where some companies were also attempting to use AWAs to reduce union influence, and where employees in the more highly remunerated parts (such as foreign exchange speculation) were hired on individual contracts. Electricity, gas and water (1.17), which had a significant drop in union density, also had a moderately high AWA/CA ratio in 2006 (Figure 4). We should be cautious in interpreting this, as it showed no AWA advantage in 2004. However, communication, finance and insurance and government administration and defence all showed high AWA/CA ratios in 2004, confirming the 2006 observations. (Figure $3)$.

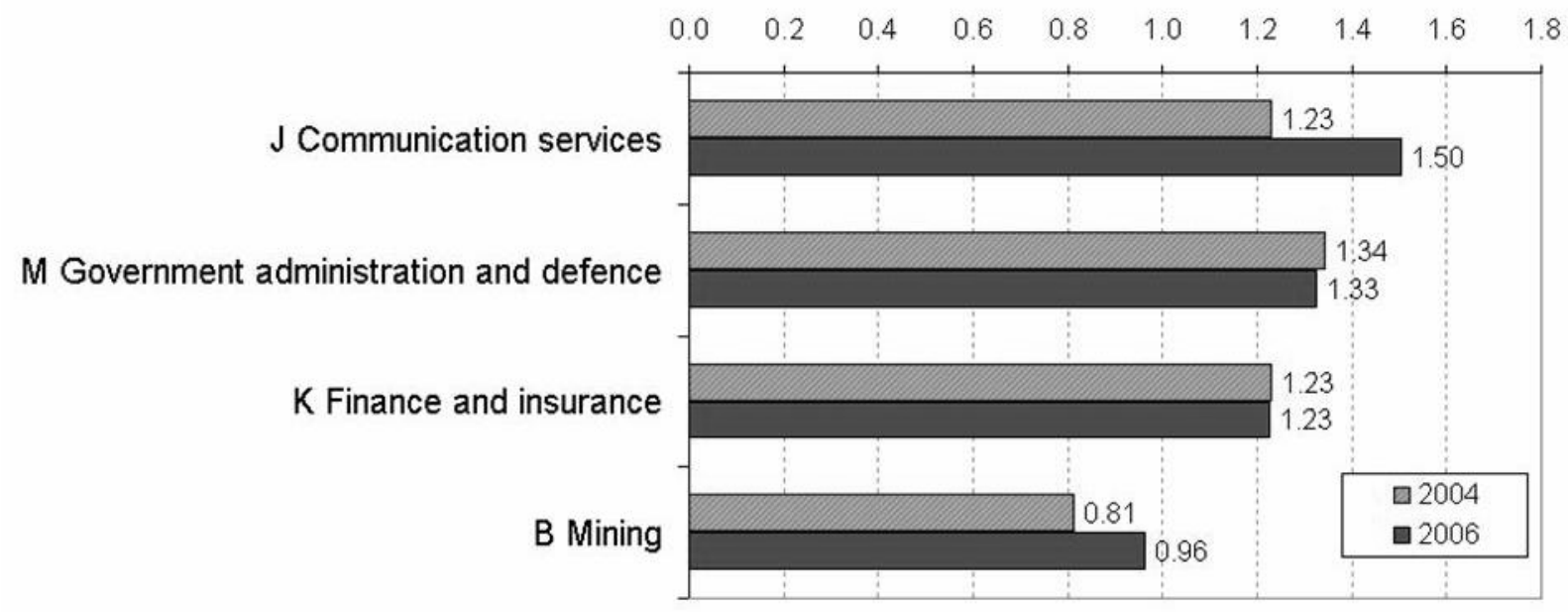

Figure 3: Ratio of AWA/CA Average Total Hourly Cash Earnings by Industry, industries with common union avoidance strategies, May 2004 and 2006

Source: unpublished data from ABS Cat No 6306.0

The only industry with extensive and well documented union avoidance strategies, but with no AWA advantage, was mining, where AWA employees earned 3.6 per cent less than CA workers. This is probably because of bifurcation between coal and metals mining. Union membership remained strong in coal sector, where the career path typically involves new entrants working for a contractor on an AWA until a permanent job in a mine, often covered by a collective agreement, can be obtained. In metals mining, by contrast, union density was so low as to not signify any threat effect. In coal mining, estimated union density in August 2006 was 66 per cent, compared to 11 per cent in metal ore mining where AWAs dominate (Australian Bureau of Statistics 6310.0). The main way AWAs reduce union influence in coal is by ensuring an alternative labour supply in case of industrial action. Workers in metal ore 
mining work 5 per cent more hours but earn 21 per cent less per week than workers in coal mining.

Retail trade also had a high AWA/CA ratio (1.18). This partly reflected the structure of retail awards and collective agreements, under which employees earning above a certain level are 'exempt' from the instrument (Price 2004). More importantly, retail trade, along with hospitality, is an industry where many non-union 'collective' agreements cut pay and conditions (Evesson et al. 2007), suppressing mean CA earnings.

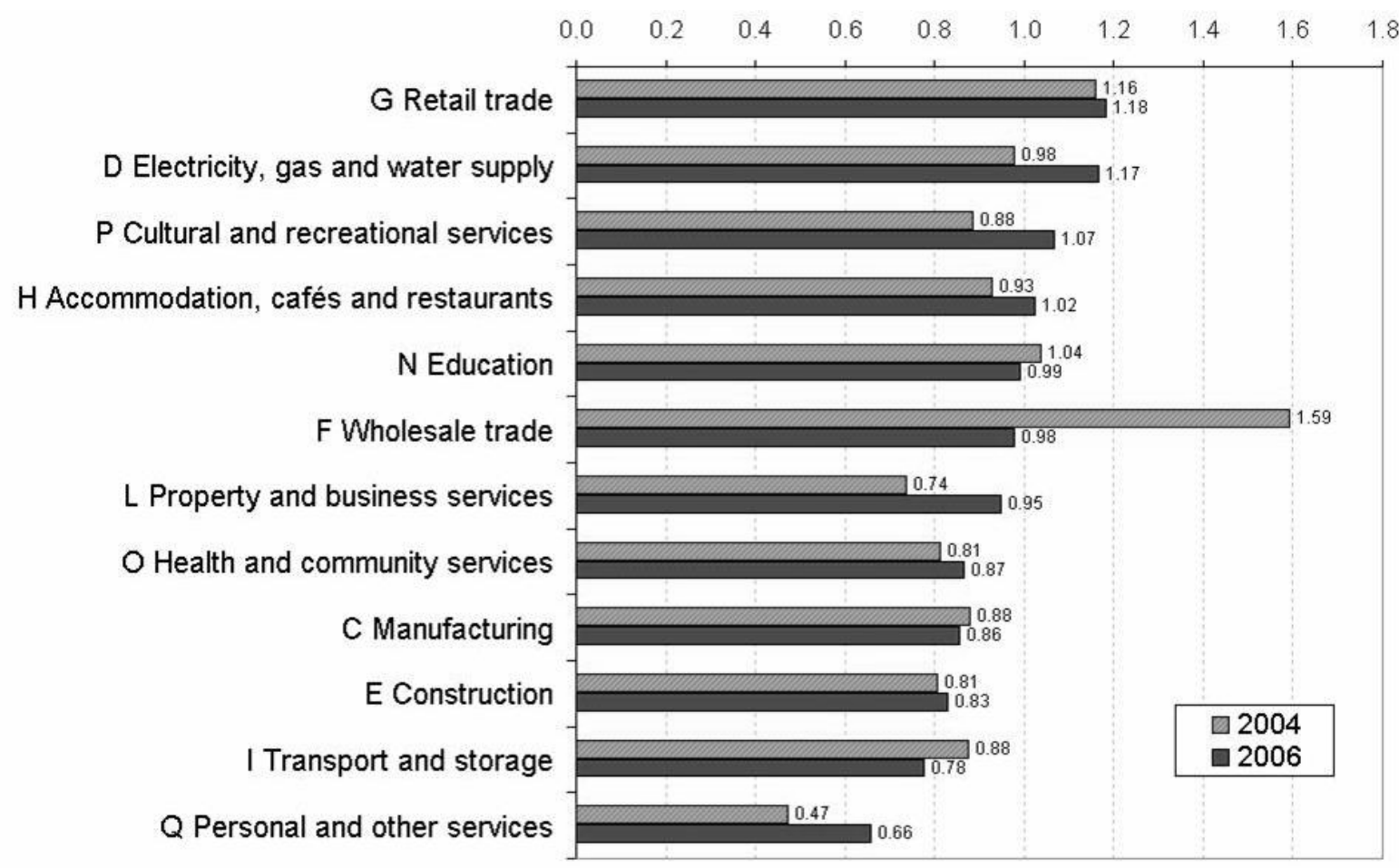

Figure 4: Ratio of AWA/CA Average Total Hourly Cash Earnings by Industry, other industries, May 2004 and 2006

Source: unpublished data from ABS Cat No 6306.0

AWAs paid on average well below CAs in: manufacturing (where the AWA shortfall was 14 per cent in 2006); construction (17 per cent); transport and storage (22 per cent); health and community services (14 per cent); property and business services (5 per cent); and personal and other services (though the high 34 per cent shortfall was influenced by the inclusion of high paying emergency service CAs). (Figure 4) 


\section{Occupation and agreements}

The Australian Standard Classification of Occupations system ranks occupations by broad skill level. Nine occupational groups are spread across five skill levels in descending order of skill. Skill level is 'a proxy for bargaining position' (van Wanrooy et al. 2007:93). Consistent with this, survey evidence shows that employees who viewed their skills as in high demand, and those on high incomes, were less likely than others to accept pay and conditions on offer without negotiation (Australian Research Group 2006).

For the top three occupational groups (covering the top two skill levels), AWA employees earned more on average than CA employees in both 2004 and 2006. Professionals were clearly a group with high labour market power.

At the other end of the labour market, labourers and related workers experienced a consistent AWA pay shortfall - their wages were 17 per cent lower than wages of workers on CAs in 2006 (and 14 per cent lower in 2004). In all, five of the six lowest occupational groups, occupying the three lowest skill level bands, revealed an AWA pay shortfall compared to CAs in 2006 (Figure 5) 


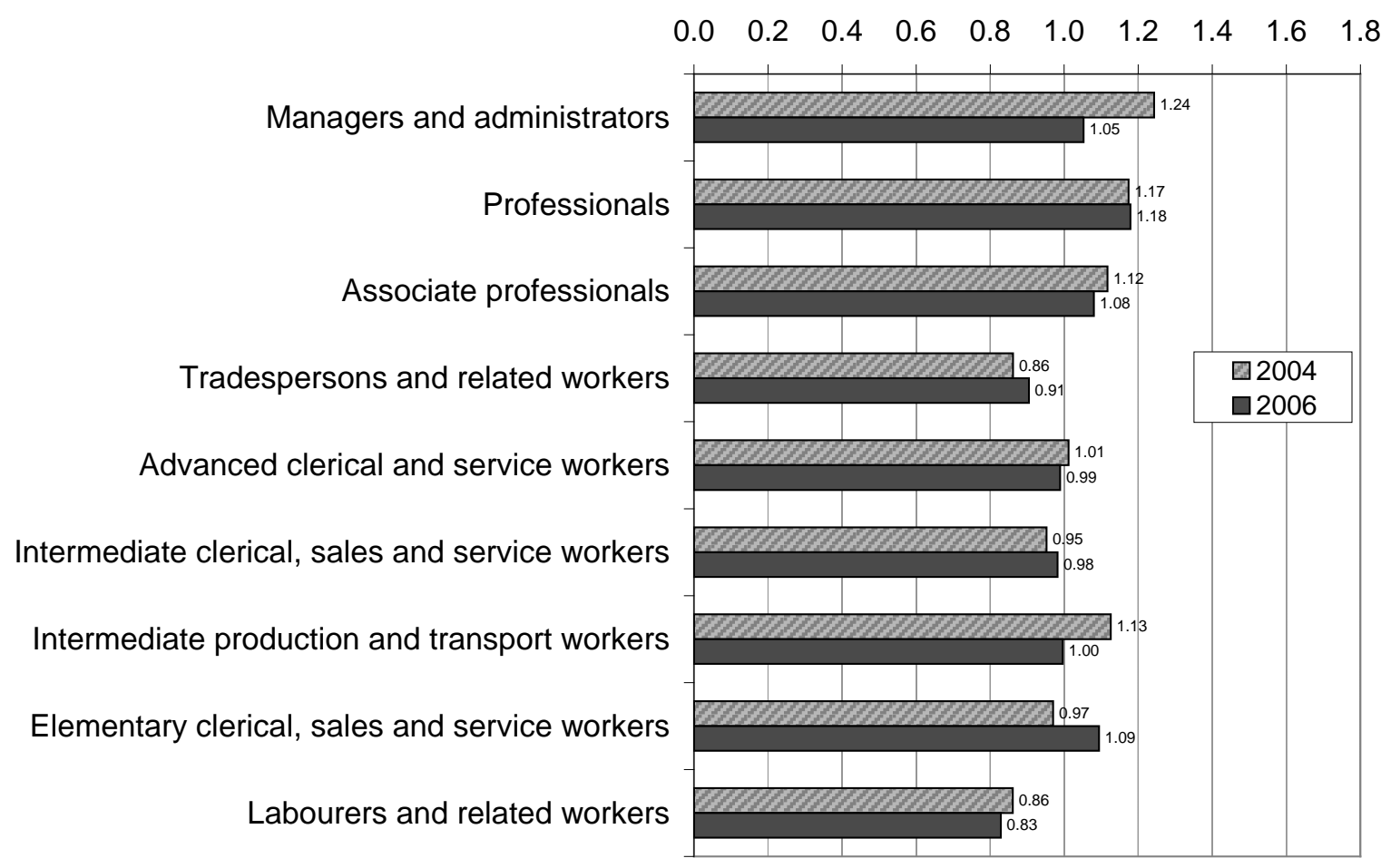

Figure 5: Ratio of AWA/CA Average Total Hourly Cash Earnings by Occupation, May 2004 and 2006 Source: unpublished data from ABS Cat No 6306.0

\section{DISCUSSION}

Several points can be readily made. First, the distribution of earnings under individual contracts in the form of AWAs was more unequal than that of earnings under collective agreements. This is consistent with theory and international experience. Second, average and especially median earnings under AWAs were lower than under collective agreements. It was the case both in aggregate and for many industries, occupations and size groups. This is consistent with individual contracting reducing the bargaining power of employees, by comparison with collective bargaining. Third, there is little to support the idea that individual contracting, of itself, raises productivity by removing union-related impediments to productivity. This scepticism arises from: the poorer overall wage outcomes for workers under AWAs; the poor productivity performance of the Australian economy during a period in which individual contracting, particularly through AWAs, grew and was actively promoted; the lack of a consistent inter-industry correlation between individual contracting and productivity growth shown in Table 1; and the low take-up of AWAs, outside two or 
three industries, by comparison with earlier expectations (cf Hamberger 1995) despite a decade of availability, which suggests little benefit for most employers from deploying them. This lack of a positive link between individual contracting and productivity is consistent with other research in Australia and New Zealand (Gilson \& Wagar 1996; Dalziel 2002; Hull \& Read 2003; Dalziel \& Peetz 2008) and with British experience (Charlwood 2007). It is also consistent with the international literature which tends to suggest that unions probably have little or no net effect on productivity, and any impact is contingent on circumstances (Addison \& Belfield 2004; Freeman 2004; Hirsch 2004; Kaufman 2004).

Fourth, the link between contracting and pay appears contingent, varying between occupations, industries and firm size, raising the question as to what causes these variations. This contingency should not surprise us: other research also indicated there were different types of AWAs that focused on different issues, (Cole, Callus \& Van Barneveld 2001). It is consistent with an earlier survey comparing employees on AWAs with a control group, which showed perceived effects of AWAs varied greatly according to employees' position in the labour market. AWA employees in managerial and professional occupations (the highest skill group) were quite satisfied, while those in other occupations were dissatisfied on several key issues, by comparison with workers not on AWAs (Peetz 2004). Labour market position appears to be a factor explaining some of the patterns we observe here too.

The other key factor helping explain outcomes is union avoidance behaviour - employers offering a non-union premium to employees through individual contracts, a form of assumed 'efficiency wage' to avoid the loss of control collective bargaining might bring. AWAs generally paid above CAs in industries where union avoidance strategies are important and below CAs in industries where labour cost minimisation was important. The findings on size are also consistent with the idea AWAs are frequently used for cost cutting or union avoidance. Very large firms and federal government departments had the resources and sophistication to mount concerted union avoidance strategies, offering wage premiums to induce workers to sign AWAs and/or financially penalising those who seek to remain on collective agreements. As economies of scale encourage unions to concentrate organising efforts in large firms, union density is on average higher there (eg Millward \& Stevens 1986; Hundley 1989; Visser 1991), so large firms have a stronger incentive to devote resources to 
non-union premiums. Indeed there is British and US evidence that union density, after mostly rising with size, decreases again in very large firms which have large human resource management capacities to discourage unionisation (Bain \& Elias 1985; Hirsch \& Berger 1984). Some large firms are prominent in industries featuring high AWA premiums (communications, finance and government administration). The AWA/CA ratio is considerably higher in the top industries identified as union avoiders, and in the largest firms with the greatest incentive to engage in union avoidance, than it is in the top occupations identified as having high skills.

Small firms are not likely to follow this approach, as threat of unionisation is low. They appear more likely to use AWAs for cost minimisation, presumably through cutting penalty rates, overtime pay and other 'protected' award conditions. The prevalence of such costcutting should not be underestimated. In the period May-September 2006, some 76 per cent of AWAs abolished shiftwork loading, 68 per cent of AWAs abolished penalty rates and 52 per cent abolished overtime pay (Davis 2007). This changing of ways in which workers are paid for the time they work is observed in other research on individual contracting in Australia and New Zealand (Mitchell \& Fetter 2003; Dannin 1997; Oxenbridge 1999). Qualitative studies, too, showed effects of WorkChoices to be 'uneven, impacting on workers differently depending on their location in particular occupations and sectors' (Charlesworth \& McDonald 2007). For more vulnerable workers, including women and workers in retail and hospitality, effects included reduced conditions and power (Elton et al. 2007; Evesson et al. 2007). It is consistent with such literature that our data show the lowest skill occupation group had the worst outcomes for workers on AWAs, while occupations with the most market power had relatively good outcomes. AWA wage shortfalls are also apparent in small firms and in sectors with low worker bargaining power such as health and community services (which includes aged care and child-care). We attribute these outcomes to the use of AWAs as a cost-cutting measure. The impact of individual contracting also appeared worse on average for women than for men, probably because of the industries and occupations in which they worked.

Structural factors also played a role in explaining patterns in specific industries. Examples include the use of exemption clauses in retail trade, the hiring of staff in high-salary areas in 
finance on AWAs, and the strong bargaining power of unionised workers in coal mining and emergency services.

\section{CONCLUSIONS}

Our findings are qualified by the facts that we were unable to apply multivariate techniques to control for individual characteristics, and that the collective agreement stream data include many employees who are on non-union agreements. This latter qualification, however, tends to strengthen our conclusions, as it leads to understatement of wages under collective agreements.

If there were 'flexibility' benefits for employees and employers through individual contracting, they were not apparent in these data at either aggregate or disaggregated levels. We found nothing to suggest that individual contracting, by increasing productivity, led to generally higher wages than would occur under collective bargaining. For the typical worker (that is, the median employee), the reverse was the case. The median AWA shortfall of 15 to 16 per cent over the two years suggested cost-minimisation was an important element in individual contract strategies, and any 'flexibility' benefits that existed were not enough to offset the cost-minimisation effects on wages. Overall, AWAs were commonly associated with poorer outcomes for 'typical' employees than collective agreements. Policy institutions clearly matter in shaping wage outcomes.

The findings are consistent with the view that individual contracting is heterogeneous (eg Cole et al. 2001) and 'optimal for those with bargaining power, but an inadequate solution for employees without bargaining power as it can be used to undermine labour standards' (van Wanrooy et al. 2007). Its effects, by comparison with collective agreements, vary according to reasons for introduction and labour market characteristics. Employers may have paid nonunion premiums (and/or apply penalties for not signing AWAs) where they use individual contracts to avoid unions. However, where organisations did not perceive a union threat effect, such as in most small firms, and were focused on cost minimisation, registered individual contracts were commonly used to reduce average pay and conditions as the legal 
environment permitted. Most affected were workers whose skills were not unique and who had limited bargaining power. For these workers, individual contracting represents a transfer of power from labour to capital.

Our findings imply that part of the reason for the widening dispersion of earnings under individual contracting is that workers with less skill and bargaining power in the labour market lose power, relative to those with highly sought after skills who are in position to obtain higher benefits through individual contracting. Another reason for the widening dispersion appears to be the offering of a non-union premium in response to a union threat effect, specifically in situations where the threat of unionism is real and workers have some individual bargaining power. The importance of employer strategies is highlighted by the greater variability of AWA/CA ratios by firm size and industry than by employee skill level. Again, the limitations of the dataset mean we must be cautious in interpreting this difference, but they point to the need to take account of union threat and avoidance effects in explaining how individual contacting affects the earnings distribution. This in turn suggests that models of union wage effects which do not take account of union threat effects on non-union wages will understate the true impact of unions on wages. Conversely, models of the impact of individual contracting on wages will understate the negative effect of individual contracting, compared to collective bargaining, unless they take account of the heterogeneity of individual contracting, including its role in responding to union threat effects. 


\section{REFERENCES}

Andrews, K. (2005). WorkChoices 7. Speech to Australian Business Limited. Sydney. 11 October.

Andrews, K. (2006). Answer to Question 2611. (reply to question asked by Mr Murphy [Lowe], 9 November 2005). Canberra, House of Representatives Hansard. 8 August.

Australian Bureau of Statistics (5204.0). Australian System of National Accounts. Canberra.

Australian Bureau of Statistics (5206.0). National Income, Expenditure and Product. Canberra.

Australian Bureau of Statistics (6306.0). Employee Earnings and Hours, Australia. Canberra. various years.

Australian Bureau of Statistics (6310.0). Employee Earnings, Benefits and Trade Union Membership, Australia. Canberra. various years.

Australian Bureau of Statistics (6345.0). Labour Price Index, Australia. Canberra. various years.

Australian Research Group (2006). Quantitative Research on Bargaining Power and Choice in the Workplace. Melbourne, Industrial Relations Victoria. February.

Baarth, E., O. Raaum \& R. Naylor (1998). Union wage effects: does membership matter. Warwick Economics Research Paper Series No 500. Warwick, University of Warwick.

Background Briefing (2000). Call centres -- the nerve centres of business. Background Briefing, Australian Broadcasting Commission. 18 June.

Bailey, J., M. Mourell \& A. Wilkinson (2009). "Whatever they call this article in whatever order of authors' names." Industrial Relations Journal.

Bain, G. S. \& P. Elias (1985). "Trade Union Membership in Great Britain: An Individual Level Analysis." British Journal of Industrial Relations 23(1): 71-92.

Bickley, M., T. Jefferson \& T. Travaglione (1999). A case study on the introduction of Australian Workplace Agreements. Report for the Office of the Employment Advocate. Sydney. June.

Blanchflower, D. G. \& A. Bryson (2003). Changes over time in union relative wage effects in the UK and US revisited. International Handbook of Trade Unions. J. T. Addison and C. Schnabel. Cheltenham, Edward Elgar.

Blinder, A. \& D. H. Choi (1990). "A Shred of Evidence on Theories of Wage Stickiness." Quarterly Journal of Economics: 1003-1015. 
Brown, W., S. Deakin, M. Hudson, C. Pratten \& R. Ryan (1998). The individualisation of employment contracts in Britain. Employment Relations Research Series No 4. London, Department of Trade and Industry.

Browne, D. (2000). Telstra tangle over "Honest Bob". Workers Online. 28 April.

Charlesworth, S. \& F. McDonald (2007). Going too far: WorkChoices and the Experience of 30 Victorian Workers in Minimum Wage Sectors. Melbourne, Industrial Relations Victoria, Department of Innovation, Industry and Regional Development. July.

Charlwood, A. (2007). "The de-collectivisation of pay setting in Britain 1990-98: incidence, determinants and impact." Industrial Relations Journal 38(1): 33-50.

Christie, V. (1992). "Union wage effects and the probability of union membership." Economic Record 68(200): 43-56. March.

Cole, M., R. Callus \& K. Van Barneveld (2001). What's in an agreement? An approach to understanding AWAs. paper to joint ACIRRT/OEA seminar. Sydney, University of Sydney. September.

Corneoa, G. \& C. Luciforab (1997). "Wage formation under union threat effects: Theory and empirical evidence " Labour Economics 4(3): 265-292.

Cowling, S. \& W. Mitchell (2006). "Taking the low road: Minimum wage determination under Work Choices." Journal of Industrial Relations 49(5): 741-756.

Dalziel, P. (2002). "New Zealand's economic reforms: An assessment." Review of Political Economy 14(1): 31-46. January.

Dalziel, P. \& D. Peetz (2008). "A Note On Perry’s Reconsideration of Macroeconomic Evidence from New Zealand " Australian Economic Review 41.

Dannin, E. (1997). Working Free: The origins and impact of New Zealand's Employment Contracts Act. Auckland, Auckland University Press.

Davis, M. (2007). Revealed: how AWAs strip work rights. Sydney Morning Herald. 17 April. Department of Employment and Workplace Relations (2006). Wage Trends in Enterprise Bargaining. Canberra, DEWR. September quarter and previous editions.

Dickens, W. (1986). Wages, Employment and the Threat of Collective Action by Workers. Working Paper, No. 1856, National Bureau of Economic Research.

Dundon, T. \& D. Rollison (2004). Employment Relations in Non-union Firms. London, Routledge.

Enterprise Initiatives (2007). Our Clients: Hotels and Pubs - The Mean Fiddler Isish Tavern, Belvedere Hotel, Grand Central Hotel and the Full Moon Hotel. . North Sydney, Enterprise Initiatives Pty Limited. 
Evesson, J., J. Buchanan, L. Bamberry, E. Frino \& D. Oliver (2007). 'Lowering the Standards': From Award to Work Choices in Retail and Hospitality Collective Agreements. Sydney, Workplace Research Centre, University of Sydney.

Fang, T. \& A. Verma (2002). "Union wage premium." Perspectives: Statistics Canada 75001-XPE: 17-23. Winter.

Forth, J. \& N. Millward (2002). "Union effects on pay levels in Britain " Labour Economics 9(4): 547-561. September.

Freeman, R. (1980). "Unionism and the dispersion of wages." Industrial and Labor Relations Review 34(1): 3-23.

Freeman, R. (2004). "What Do Unions Do ? The 2004 M-Brane Stringtwister Edition." Journal of Labor Research 26(4): 642-668. Fall.

Freeman, R. B. \& J. L. Medoff (1984). What Do Unions Do? New York, Basic Books.

Gilson, C. \& T. Wagar (1996). "Individual contracts and the impact of labour legislation: trans-Tasman comparisons." Australian Bulletin of Labour 22(4): 275-287. Dec 1996.

Hamberger, J. (1995). "Individual contracts: What do they mean for Australia?" Economic and Labour Relations Review 6(2): 288-99.

Hearn Mackinnon, B. (2007). Behind WorkChoices: How one Company Changed Australia's Industrial Relations. Melbourne, Heidelberg Press.

Hildreth, A. K. G. (2000). "Union wage differentials for covered members and nonmembers in Great Britain " Journal of Labor Research 21(1): 133-147.

Hirsch, B. T. \& M. C. Berger (1984). "Union Membership Determination and Industry Characteristics." Southern Economic Journal 50(3): 665-79. January

Hull, D. \& V. Read (2003). Simply the Best: Workplaces in Australia. Working Paper 88. Sydney, ACIRRT, University of Sydney. December.

Kornfeld, R. (1993). "The effects of union membership on wages and employee benefits: The case of Australia." Industrial \& Labor Relations Review 47(1): 114-28. October.

McDonald, J. \& N. Timo (1996). Killing the union? Individualised contracts and CRA. Contemporary Research on Unions: Membership, Organisation, Marginalisation and Non Standard Employment. G. Griffin. Melbourne., National Key Centre in Industrial Relations, Monash University.

McIlwain, P. (2006). evidence to November Estimates hearing. Canberra, Senate Employment, Workplace Relations and Education committee. 2 November.

Metcalf, D. (1982). "Unions and the distribution of earnings." British Journal of Industrial Relations 20(2): 163-169. 
Miller, P. \& S. Rummery (1989). "Unionism and the structure of male wages in the labour market." Journal of Industrial Relations 31(2): 185-211. June.

Mitchell, R. \& J. Fetter (2003). "Human resource Management and individualisation in Australian law." Journal of Industrial Relations 45(3): 292-325. September.

Organisation for Economic Cooperation and Development (1994). The OECD Jobs Study: Facts, Analysis, Strategy. Paris, OECD.

Organisation for Economic Cooperation and Development (2001). Innovation in Labour Market Policies: The Australian Way. Paris, OECD.

Organisation for Economic Cooperation and Development (2004a). Economic Survey of Australia 2004: Economic performance and key challenge. Paris, OECD.

Organisation for Economic Cooperation and Development (2004b). Employment Outlook. Paris.

Organisation for Economic Cooperation and Development (2006a). Boosting Jobs and Incomes: Policy Lessons from Reassessing the OECD Jobs Strategy. Paris.

Organisation for Economic Cooperation and Development (2006b). Employment Outlook: Boosting Jobs and Incomes. Paris.

Organisation for Economic Cooperation and Development (2008). wages distribution spreadsheet. Paris.

Oxenbridge, S. (1999). The individualisation of employment relations in New Zealand: Trends and outcomes. Employment Relations: Individualisation and Union Exclusion - An International Study. S. Deery and R. Mitchell. Sydney, Federation Press: 227-50.

Peetz, D. (2004). How well off are employees under AWAs? Reanalysing the OEA's employee survey. New Economies: New Industrial Relations, Noosa, Association of Industrial Relations Academics of Australia and New Zealand. February.

Peetz, D. (2006). Brave New Workplace: How Individual Contracts are Changing our Jobs. Sydney, Allen \& Unwin.

Preston, A. C. \& T. Jefferson (2007). "Trends in Australia’s Gender-Wage Ratio." Labour \& Industry 18(2): 69-84.

Price, R. (2004). Checking out supermarket labour usage: The nature of labour usage and employment relations consequences in a food retail firm in Australia. Department of Industrial Relations. Brisbane, Griffith University. 27 April. PhD.

Rubery, J. (1997). "Wages and the Labour Market." British Journal of Industrial Relations 35(3): 337-366. 
Teicher, J., A. Pyman, P. Holland \& B. Cooper (2007). Employee Voice in Australia. What Workers Say: Employee Voice in the Anglo-American World. R. B. Freeman, P. Boxall and P. Haynes. Ithaca NY, ILR Press.

Van den Broek, D. (2003). "Recruitment strategies and union exclusion at two Australian call centres." Relations Industrielles 58(3): 515-36. Summer.

van Wanrooy, B., S. Oxenbridge, J. Buchanan \& M. Jakubauskas (2007). Australia at Work: The Benchmark Report. Sydney, Workplace Research Centre, University of Sydney. September.

Wooden, M. (1999). "Individual agreement-making in Australian workplaces: incidence, trends and features." Journal of Industrial Relations 41(3): 417-45. September.

Wooden, M. (2000). Union Wage Effects in the Presence of Enterprise Bargaining. Melbourne Institute Working Paper No 7/00. Melbourne, Melbourne Institute of Applied Economic and Social Research, University of Melbourne. April.

Workplace Express (2005). CPSU accuses DEWR of threatening merit selection through AWAs. Workplace Express. 15 April.

Workplace Research Centre (2006). "The impact of WorkChoices on agreement making - a first glance." ADAM Report 50: 9-19. September.

World Competitive Practices (1999a). OEA Case Study - Peabody Resources (Ravensworth Mine). November.

World Competitive Practices (1999b). OEA Case Study: Telstra. Report for the Office of the Employment Advocate. Sydney. November. 